\title{
Pre-Carolingian Typography on the Church Murals of Cappadocia
}

\author{
Cinla Seker* \\ Department of Fine Arts Education, Dokuz Eylul University, Turkey
}

Submission: February 13, 2020; Published: February 26, 2020

*Corresponding author: Cinla Seker, Department of Fine Arts Education, Dokuz Eylul University, Turkey

\begin{abstract}
Typography, which is the arts \& crafts of writing is born and developed parallel to the human development. As a way of expression writing used in products of culture and depends on the characteristics of the culture. The aim of this paper is to put forward the characteristics of the typography used in the church murals of Cappadocia region before Carolingian Renaissance, which has begun in late 8th century and spread into Byzantine - Eastern Roman Empire. The first Roman lettering used called Rustic Capitals and dated back to the first century ADs. By the end of the $1^{\text {st }}$ millennium another way of lettering was on its way. The last type version before the humanist miniscule - lower cases seen on the church murals of Cappadocia region in high Middle Ages style. By analyzing the typography on the church murals formally and contextually a Cappadocian version can be defined and placed in between the steps of the huge metamorphoses of Latin lettering and related to the great history of writing and typography.
\end{abstract}

Keywords: Typeface design; Typography; Writing; Cappadocia

\section{Introduction}

Typography, which is the arts \& crafts [1] of writing is born and developed parallel to the human development in the form of marks made by man. As a 20th century invented term typography today became a field of study, which is graphic designers and typeface designers' concern. Graphic design with its broadening content covers every two-dimensional surface by type and image according to its targeted functions [2] by digitally printing or digitally screening. While designing graphically, typefaces needed in the forms of fonts - ready to use in the software, which created to use in digital design. And typeface designers both should decide the form of a new set of alphabets with same characteristics and by considering their legibility should generate them in the font form in other words ready to use [3]. In order to be successful typeface, font and graphic designers have to know the history of typography and lettering.

As a way of expression writing used in products of culture and its form and function depends on the characteristics of the culture. On its developmental stages it differs from time to time, culture to culture. After pictorial writing like hieroglyphs of ancient Egypt or logographic characters of ancient China first alphabet, in which every letter symbolizes a sound invented by Phoenicians in 1200BC in east Mediterranean Sea while making trade [4].

The Phoenician alphabet first adopted by Greeks, then by Roman and spread all Europe then to America [5]. While the letters of an alphabet changing, different writing styles also occurred. These styles of Latin alphabet called Roman, which Rustic derived from; Greek Uncial, which Uncial derived from, and Half Uncial, which is derived from Rustic and Uncial [6]. Many contemporaries were accompanying throughout Europe to Half Uncial stage but in different styles, which make the communication impossible or difficult even in Europe towards the end of the eighth century [7]. The main limitation of writing had been always the material, which letters writing on, writing with and writing by. While primitive form of paper, clay tablets, marble and parchment were different surfaces human wrote, stylus, chisel, brush and sticks were different writing tools and chalk, coal, soot and oil were different writing mediums $[8,9]$. All these materials formed writing visually until Charlemagne I, the emperor of the expanded Frankish state at the beginning of the ninth century, who attempted to standardize the European script $[10,11]$. This is why Humanist Miniscule (lower cases) were invented as a part of Carolingian Renaissance, which has begun in late 8th century by these attempts of the emperor and how all these spread into Byzantine - Eastern Roman Empire McKitterick (2004).

Goreme is a district in the Cappadocia region, which lays in the left side of the Euphrates River's 250th kilometers' point in the east central Anatolia. The region was under the Roman rule, became Byzantine after the fall of Western Rome in 407AD [12]. As one of the six churches of Goreme, Apple Church (Turkish: Elmali 


\section{Global Journal of Archaeology \& Anthropology}

Kilise) has been chosen as an introduction for future researches [13]. As a small size cave church, Apple Church carved in the ash and lava formed soft rocks of Mount Argaeus (Turkish: Erciyes), which erupted 2.6 million years ago [14]. On the four pillars -as a sign of Greek cross- organized church has colourful murals in
Byzantine art after the second iconoclast period ended in 842AD [15]. On the murals, besides saints, bishops and martyrs -names also seen-there are scenes like Last Supper combined with Greek upper-case letters read as FISH with an acrostic meaning Jesus Christ, Son of God, and Savoir [16].

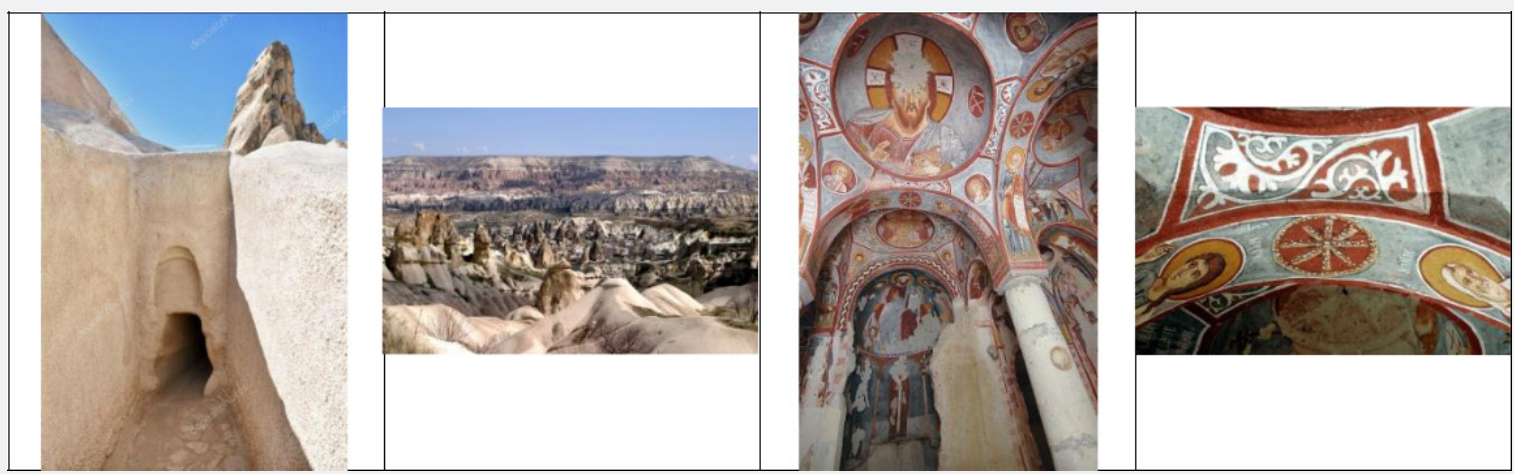

Figure 1: Apple Curch in Goreme, entrance, out \& inside.

History of writing and typography studies analysed the transformation steps of writing according to time, region and style/visual characteristics and defined \& named after. The aim of this paper is to analyse and put forward the characteristics of the typography used in the church murals of Cappadocia, which dated back after 842AD. By analyzing the typography on the church murals initially of the Apple Church and later other five churches formally and contextually, it is expected to see whether a Cappadocian version, which is local and unique can be defined and placed in between the steps of the huge metamorphoses of lettering and related to the great history of writing and typography (Figure 1).

The Analysis

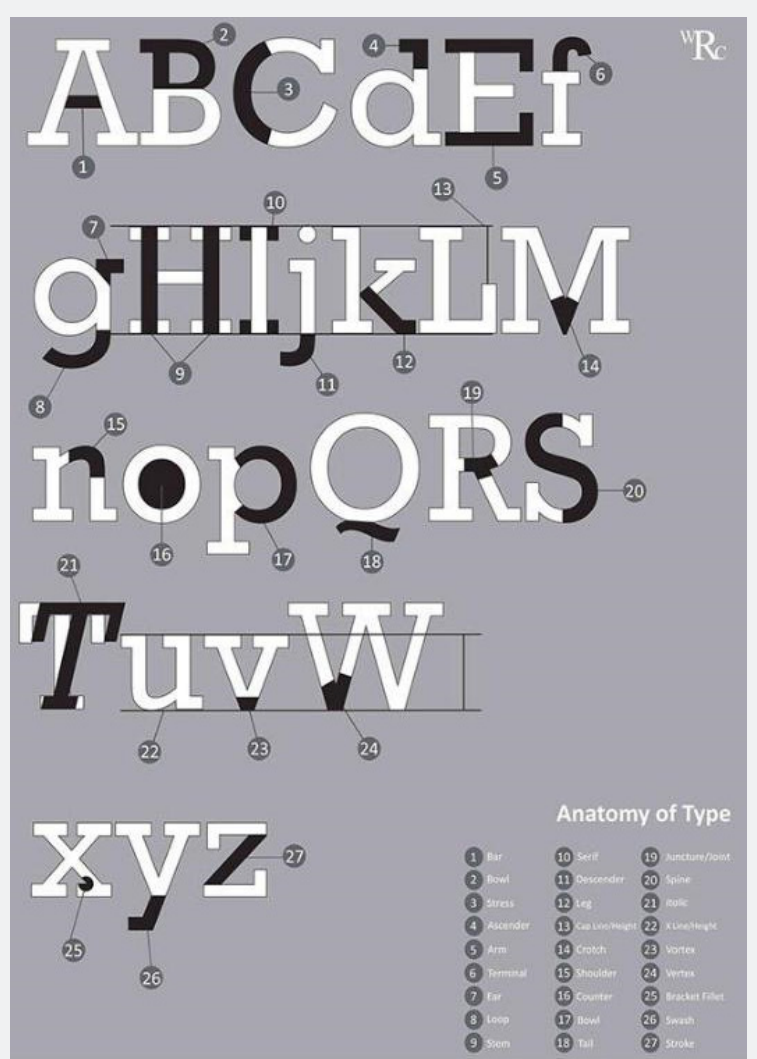

Figure 2: The anatomy of type. 
Every glyph [17] of an alphabet has formal characteristics which are special and unique. The analysis intended made by comparing the letters with the similar manner seen on (Figure 2), which belong to the Latin alphabet, which is similarly derived from the Greek one [17]. The black parts of letters used to take the attention on the formal design's qualifications of different glyphs. On (Figure 3) there are four captures seen from Apple Church with Greek alphabet lettering. On the fallowing figures the pictures seen in detail inverted as colours scheme and high levels of brightness \& contrast applied to make the letters more visible. These details placed with a table of Greek alphabet in different centuries side by side to find a connection in between or vice versa. The table formed with 12 columns representing the 11 different styles from 11 different centuries based on real documents and 24 rows consisting 23 different glyphs -any element of writing- of the Greek alphabet [18].

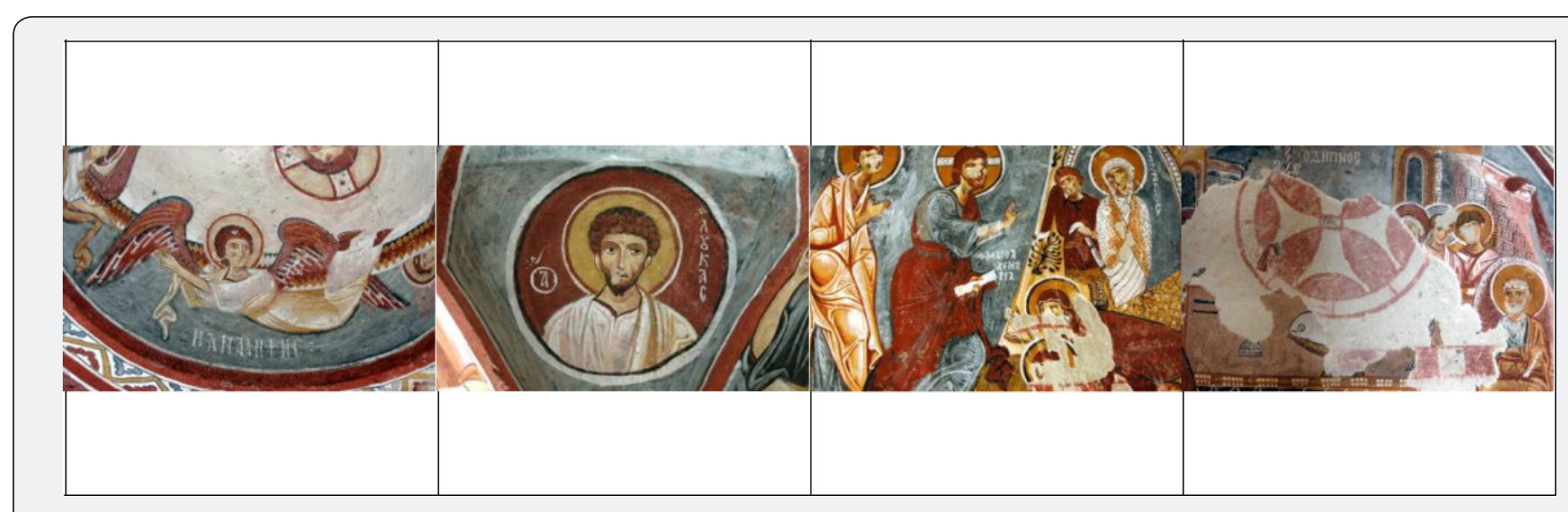

Figure 3: Scenes from Apple Church Murals.

On the second column the letters from Rosetta Stone, an inscription dated $193 \mathrm{BC}$ for understanding the differences. On the third column a papyrus of New Testament presented. All reminding columns are representing different codex's from different centuries called Codex Sinaiticus, Codex Vaticanus,
Codex Alexandrinus, Codex Bezae, Codex Petropolitanus, Codex Regius, Codex Basiliensis, Koridethi Codex and finally Codex S, which is a clear example of the exaggerated thin-and-thick Slavic style (www.skypoint.com). (Figures 4-6). On every sample the same style glyph marked as seen on Figure.

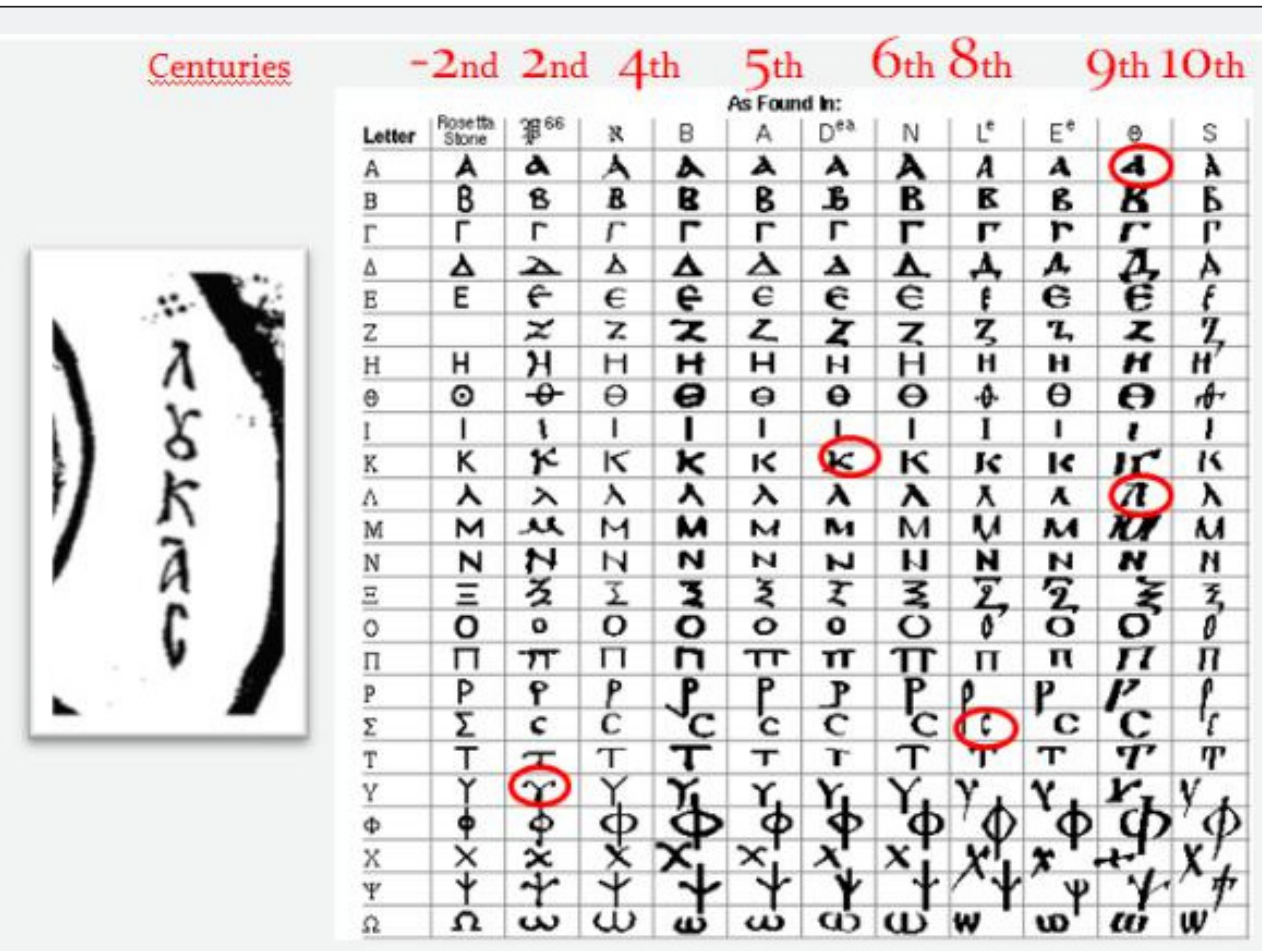

Figure 4: The formal analysis according to centuries. 

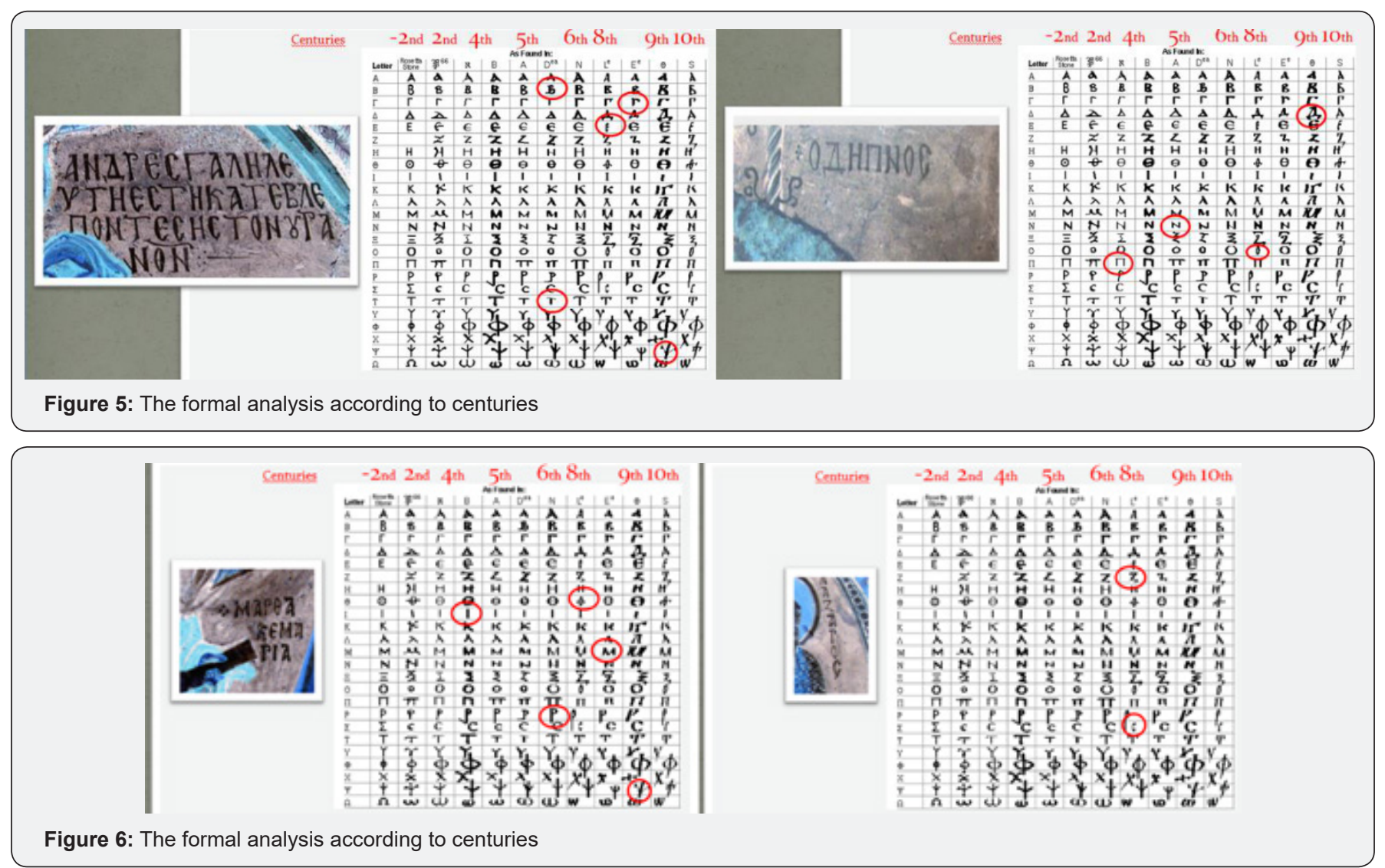

On (Figure 5), when examined in detail it is easily seen that only two glyphs belong to 9th century, seven glyphs from three different centuries. On Figure 6, when examined in detail it is easily seen that only a glyph belongs to 9th century, six glyphs from three different centuries.

\section{Conclusion}

The church murals of Cappadocia -in this instance Apple Church- analysed and put forward the characteristics of the typography used in. Every letter used in the Apple Church murals, which located in Goreme district in Cappadocia region written by combining different glyphs from different centuries that are formally varied. It is definite that a step in the adventure of lettering called as a Cappadocian version/style, which is local and unique can be defined and placed in between the steps of the huge metamorphoses of lettering, which related to the great history of writing and typography. It is advised that after this analysis, other five churches may be analysed in same manner, and step by step the scope of the research broaden to see the limits and effects of the defined Cappadocian version lettering.

\section{References}

1. Baines P, Haslam A (2005) Type \& Typography. Lawrence King Publishing: London.

2. Shaughnessy A (2005) How to be a Graphic Designer, Without Losing Your Soul. City Road: Lawrence King Publishing.
3. Jones S (2012) Text and Context: Document Storage \& Processing. Springer: London.

4. Marston E (2001) The Phoenicians: Cultures of the Past. New York: Benchmark Books. McKittering R (2004) History and the Memory in the Carolingian World. Cambridge: Cambridge University Press.

5. Vlassopoulos K (2013) Greeks and Barbarians. Cambridge: Cambridge University Press.

6. Kipfer BA (2000) Encyclopedic Dictionary of Archaeology. Kluwer Academic/Plenum Publishers. New York.

7. Willen B, Strals N (2009) Lettering \& Type: Creating Letters and Designing Typefaces. New York: Princeton Architectural Press.

8. Fischer SR (2003) A History of Writing. Reaktion Books, London.

9. Harris MH (1999) History of Libraries of the Western World: ( $4^{\text {th }}$ Edn). Lanham: Scarecrow Press.

10. Lemerle P (2017) Byzantine Humanism: The First Phase: Notes and Remarks on Education and Culture in Byzantium from its Origins to the Tenth Century. Leiden: Brill.

11. Smith L, Leyser C (2016) Motherhood, Religion, and Society in Medieval Europe, 400-1400: Essays Presented to Henrietta Leyser. Oxon: Routledge.

12. Lee AD (2013) From Rome to Byzantium: AD 363 to 565: The Transformation of Ancient Rome. Edinburgh: Edinburgh University Press.

13. Ousterhout R (2005) A Byzantine Settlement in Cappadocia: Dumbarton Oaks Studies XLII. Washington D.C.: Dumbarton Oaks.

14. Olsen B (2004) Sacred Places around the World: (2 ${ }^{\text {nd }}$ Edn): 108 Destinations. San Francisco: CCC Publishing. 
15. Doniger W (1999) Merriam Webster's Encyclopedia of World Religions. Springfield: Merriam-Webster.

16. Jensen RM (2012) Baptismal Imagery in Early Christianity: Ritual, Visual, and Theological Dimensions. Grand Rapids: Baker.

This work is licensed under Creative Commons Attribution 4.0 License DOI: 10.19080/GJAA.2020.11.555811
17. Morris RL (1988) Runic and the Mediterranean Epigraphy: Nowele Supplement Series 4. Amserdam: Odense University Press.

18. Byrne B, Braha Y (2012) Creative Motion Graphic Titling for Film Video and the Web. Burlington: Focal Press.

\section{Your next submission with Juniper Publishers will reach you the below assets}

- Quality Editorial service

- Swift Peer Review

- Reprints availability

- E-prints Service

- Manuscript Podcast for convenient understanding

- Global attainment for your research

- Manuscript accessibility in different formats

( Pdf, E-pub, Full Text, Audio)

- Unceasing customer service

Track the below URL for one-step submission https://juniperpublishers.com/online-submission.php 